\title{
An Evaluation of the Job Analysis Process in the Private Commercial Banks of Bangladesh
}

\author{
Md. Nafizur Rahman (Corresponding Author) \\ Department of Business Administration in Finance \& Banking \\ Bangladesh University of Professionals \\ Mirpur Cantonment, Dhaka 1216, Bangladesh \\ E-mail: nafizrahman23@gmail.com \\ Nowshin Nower \\ Department of Business Administration in Finance \& Banking \\ Bangladesh University of Professionals \\ Mirpur Cantonment, Dhaka 1216, Bangladesh \\ E-mail: khannowshin49@gmail.com
}

Received: Jan. 28, 2020 Accepted: Feb. 24, 2020 Online published: Feb. 26, 2020

doi:10.5296/ijhrs.v10i1.16332ＵRL: https://doi.org/10.5296/ijhrs.v10i1.16332

\begin{abstract}
Banking sector of Bangladesh has been playing a pivotal role in the journey towards achieving sustainable development goal. To keep contributing to the economy it is necessary for the banks to hire and retain effective and efficient human resources. Thus, job analysis became an important strategic tool through which the banks can maintain an effective human resource management while influencing the overall performance of the bank. Hence, this study was designed to evaluate the current job analysis process practiced in the private commercial banks of Bangladesh. The study used both primary and secondary data to assess the job analysis process. A total number of 223 private bank employees from 12 banks were surveyed. A structured questionnaire with 5 point Likert scale was used to collect information from the respondents. The data was analyzed using descriptive statistics such as frequency, percentile, skewness, kurtosis and inferential statistical techniques such as, Exploratory factor analysis, Confirmatory Factor Analysis, Structural Equation Modeling and Multiple regression analysis. Results show that factors such as, data collection process and employee
\end{abstract}


involvement, data authenticity and proper documentation, and training job analyst and developing job analysis method are significantly related to the overall evaluation of job analysis in private commercial banks of Bangladesh. Thus, the study recommends that HR managers of the banks should focus more on developing effective job analysis method, data collection process, maintain data authenticity and training the job analysts for getting maximum benefit from job analysis.

Keywords: effective job analysis method, data collection, data authenticity, training job analysts, structural equation modeling

\section{Introduction}

An increasing number of management and HR experts have asserted over the previous two decades that investment in sound HR methods and services pays off to an organization through improved productivity and higher financial output. (Drucker, 2002). Organizations recognized that they can only succeed in the environment characterized by drastic and constant industrial transition and financial growth by predicting and taking action directed at creating and maintaining the required and trained staff, as well as proper management of human assets.

Job analysis is one of human resource managers ' major activities. It leads to two significant documents, work description and work specification. Manpower planning is done based on them, whether it is about strategic planning of human capital or as part of a company's regular planning. At this point of HR development in the nation, it is important to check the environmental scenario to conclude which modifications are essential for organizations to bring in their intellectual capital management for improving their efficient functioning.

Job analysis organizes data such as duties, knowledge, skills, abilities and other qualities known as KSAO-Knowledge, Skill, Ability and other personal traits for that position. This activity has to be constantly handled by human resources executives because it is the foundation for manpower planning, providing significant data needed for training and development programs and work specification. Efficient manpower planning involves meeting existing and future staff needs. The manager guarantees that staff needs are met through continuous analysis of performance goals, job requirements and available staff, combined with knowledge of labor laws.

Job analysis is a vital HR activity for the banking sector to ensure that the right person is hired at the right position. The banking industry of Bangladesh is contributing largely on the economic growth of the country. Thus, efficient human resource management is a challenging task in the private banks of Bangladesh. To maintain and retain the human capital the human resource managers have to conduct job analysis on a regular basis. Hence, this study aims at evaluating the job analysis practiced in the private commercial banks of Bangladesh.

\section{Objectives of the Study}

The primary objective of this study is to investigate the job analysis process performed in the private commercial banks of Bangladesh. The specific objectives are: 


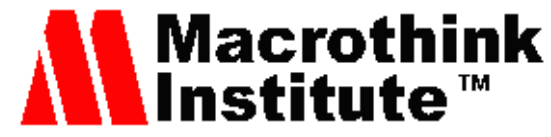

I. To identify the key job analysis techniques.

II. To identify the factors concerning the effectiveness of job analysis process.

III. To identify the significant factors that are related to job analysis process practiced in the private commercial banks in Bangladesh.

\section{Literature Review}

Job analysis can be termed as a function of scrutinizing a job to provide a general description of its elements. (Holst \& Pancoast, 1921). Job analysis refers to a systematic and detailed study of job related information such as skills, knowledge and responsibilities related to the specific job position. This information varies from one job to another and works as a determination of the success of an employee in carrying out his job responsibilities. (PPMS, 2018). Job analysis has been defined as the vital component for nearly all human resource management functions (Prien, et al., 2009) and 'the basis for solving essentially all human resource problems. (Brannick, 2007).

Job analysis is the pillar of the most key HR activities that can perform numerous functions in an organization. (Byars \& Rue, 2006). It is vital to recruitment, selection, socialization, training and development, performance appraisal and compensation of employees. In case of selection of human resources, job analysis would increase the accurateness of selection criteria. A noteworthy development has been seen during the last three decades regarding job analysis process. (Pearn \& Kandola, 1993). In order to accurately analyze a particular job, suitable techniques and methods must be applied in the collection of data on such work. Such techniques and methods include personal observation, private interview, questionnaire-based data collection, and record review. (Pinnington \& Edwards, 2000).

Job analysis is performed for several reasons. A list of outcomes of the job analysis was created by different scholars. (Prien, 1977; McCormick, et al., 1979; Ash \& Levine, 1980 and Ash, 1988). The major outcomes are: job description, job specification, job evaluation, job design, human resource attributes, performance appraisal, training and development, job succession planning etc.

(Rehman, 2009) investigated the influence of job analysis on the job performance in the Pakistani public sector organizations. The study demonstrated that analysis, evaluation and retention of job with the mediating variable recruitment knowledge, skill and ability have greater impact on the performance of employees in any organization. This study demonstrated that the first step of any recruitment process is the accurate analysis of the specific job. (Suthar, et al., 2014) examined the impact of job analysis on the performance of the public sector enterprises in India. The study found that, a regular analysis of job significantly influences employee motivation and job satisfaction. Because, job analysis ensures the right person is selected at the right position in the right time. The results showed that job analysis of a specific job can enhance the performance of an organization at greater extent.

(Singh, 2008) studied the changing nature of organizations and importance of strategic job 


\section{Macrothink}

International Journal of Human Resource Studies

ISSN 2162-3058

2020, Vol. 10, No. 1

analysis as a vital HR tool in those organizations. The researcher proposed a strategic job analysis framework which is essential for the evolution of conventional job analysis process to tackle the emerging needs of today's organizations. According to the study, the strategic job analysis process should include environmental analysis or job scan, a focused internal analysis, preparing for future job, conducting gap analysis, evaluating effectiveness and establishing validity of procedures. Hence, this study aims at examining the practice of job analysis process in the private commercial banks of Bangladesh. To conduct this research following hypotheses were proposed:

H1: Data collection process and employee involvement have significant impact on the job analysis process

H2: Data authenticity and proper documentation have significant impact on the job analysis process

H3: Training job analyst and developing job analysis method have significant impact on the job analysis process

H4: Identifying the purpose of job analysis has significant impact on the job analysis process.

\section{Research Methods}

The purpose of this research was to investigate the job analysis process practiced in the Bangladeshi private commercial banks. This study includes both descriptive and exploratory research design.

\subsection{Sources of Data}

This research is based on both primary and secondary information. Secondary data were gathered from different local and international published journal articles, book chapter and websites. The secondary data was mainly required to review the literature. On the other side, primary data were collected from the private bank employees through direct and online survey.

\subsection{Demographic Information of the Respondents}

This research conducted survey on 223 private bank employees of Bangladesh. Among them 60.1 percent were male and 39.9 percent were female. The respondents of this study were mostly aged at 36 to 41 years (34.1\%), followed by 30 to 35 (29.6\%), 24 to $29(18.4 \%)$, above 41 years $(13.9 \%)$ and 18 to 23 years (4\%). 70.4 percent of the employees were found to be married and only 29.6 percent were unmarried. Most of the bank employees were with 4-6 years-experience, followed by 7-9 years, 1-3 years, <1 years and above 10 years-experience. (Table 1). 
Table 1. Demographic Information of the Respondents

\begin{tabular}{|c|c|c|c|c|}
\hline & Frequency & Percent & Valid Percent & $\begin{array}{l}\text { Cumulative } \\
\text { Percent }\end{array}$ \\
\hline \multicolumn{5}{|l|}{ Gender } \\
\hline Male & 134 & 60.1 & 60.1 & 60.1 \\
\hline Female & 89 & 39.9 & 39.9 & 100.0 \\
\hline Total & 223 & 100.0 & 100.0 & \\
\hline \multicolumn{5}{|l|}{ Age } \\
\hline 18 to 23 & 9 & 4.0 & 4.0 & 4.0 \\
\hline 24 to 29 & 41 & 18.4 & 18.4 & 22.4 \\
\hline 30 to 35 & 66 & 29.6 & 29.6 & 52.0 \\
\hline 36 to 41 & 76 & 34.1 & 34.1 & 86.1 \\
\hline Above 41 & 31 & 13.9 & 13.9 & 100.0 \\
\hline Total & 223 & 100.0 & 100.0 & \\
\hline \multicolumn{5}{|c|}{ Marital Status } \\
\hline Unmarried & 66 & 29.6 & 29.6 & 29.6 \\
\hline Married & 157 & 70.4 & 70.4 & 100.0 \\
\hline Total & 223 & 100.0 & 100.0 & \\
\hline \multicolumn{5}{|c|}{ Work Experience } \\
\hline$<1$ Years & 24 & 10.8 & 10.8 & 10.8 \\
\hline $1-3$ years & 51 & 22.9 & 22.9 & 33.6 \\
\hline 4-6 years & 83 & 37.2 & 37.2 & 70.9 \\
\hline 7-9 years & 60 & 26.9 & 26.9 & 97.8 \\
\hline$>10$ years & 5 & 2.2 & 2.2 & 100.0 \\
\hline Total & 223 & 100.0 & 100.0 & \\
\hline
\end{tabular}




\section{Macrothink}

International Journal of Human Resource Studies

ISSN 2162-3058

2020, Vol. 10, No. 1

\subsection{Sample Design}

The sample size of this study was 223. 250 questionnaires were distributed for data collection. Among them 223 bank employees of 12 private commercial banks responded and participated in this research work. Non probability sampling technique such as, convenience sampling was adopted for sample selection.

\subsection{Questionnaire Design}

This research used the structured questionnaire developed by (Dabholkar, 1996) to collect information from the private bank employees of Bangladesh. Responses to the questions were measured with a five point Likert scale where ' 1 ' stands for 'strongly disagreed' and ' 5 ' stands for strongly disagreed. (Luthans, 2002). The reliability test shows that Cronbach's alpha is .906 which reflects strong internal consistency of the questionnaire. (Nunnally, 1978).

Table 2. Reliability Statistics

\begin{tabular}{|l|l|}
\hline Cronbach's Alpha & N of Items \\
\hline .906 & 58 \\
\hline
\end{tabular}

\subsection{Data Analysis Techniques}

Data of demographic information such as, gender, age, relationship status and work experience were processed by descriptive statistics. Descriptive statistical tools such as, frequency, percentile, skewness and kurtosis were used in this research. The respondents' opinions were analyzed using different inferential statistics such as, exploratory factory analysis, confirmatory factor analysis, structural equation modeling and multiple regression analysis. These analytical tools were used to identify the significant factors concerning the evaluation of job analysis process in private commercial banks of Bangladesh.

\section{Results and Interpretations}

This section of the research discusses the results of the Exploratory factor analysis (EFA), Confirmatory Factor Analysis (CFA) and Multiple Regression Analysis. (MRA).

\subsection{Results of Exploratory Factor Analysis (EFA)}

The appropriateness of factor analysis in this study was measured with the help of Kaiser-Meyer-Olkin Measure of sampling adequacy and Bartlett's Test of Sphericity. If the KMO and Bartlett's Test of Sphericity is at significant level, factor analysis can be conducted in the study (Hair et al., 2010). According to (Kaiser, 1974) the minimum standard of KMO value is 0.5 and value above 0.7 is highly recommended. Table 3 shows that KMO value is 0.856 and Bartlett's test of sphericity is significant $(p=000)$, which implies the aptness of factor analysis in this study. 
Table 3. KMO and Bartlett's Test

\begin{tabular}{|c|c|}
\hline Kaiser-Meyer-Olkin Measure of Sampling Adequacy. & .856 \\
\hline Approx. Chi-Square & 990.574 \\
\hline Bartlett's Test of Sphericity & 153 \\
\hline Sig. & .000 \\
\hline
\end{tabular}

Table 4 shows the communalities of the variables concerning the evaluation of job analysis process in private commercial banks of Bangladesh are very high indicating the relevance of all the variables in this study.

Table 4. Communalities of Variables

\begin{tabular}{|l|l|l|}
\hline & Initial & Extraction \\
\hline 1. My company identifies the purpose of job analysis & 1.000 & .517 \\
\hline $\begin{array}{l}\text { 2. The bank determines who will conduct job analysis work } \\
\text { 3. Expert or HR people determine the way to conduct job analysis } \\
\text { process }\end{array}$ & 1.000 & .394 \\
\hline $\begin{array}{l}\text { 4. Experts don't have any personal likes and dislikes when it comes } \\
\text { to analyze a job }\end{array}$ & 1.000 & .483 \\
\hline $\begin{array}{l}\text { 5. The bank develops a planned approach about how to carry the } \\
\text { whole process in order to investigate a specific job }\end{array}$ & 1.000 & .513 \\
\hline $\begin{array}{l}\text { 6. Company decides the extent of employee involvement in the job } \\
\text { analysis process }\end{array}$ & 1.000 & .494 \\
\hline $\begin{array}{l}\text { 7. My company decides the level of details to be collected and } \\
\text { recorded in the analysis process }\end{array}$ & 1.000 & .566 \\
\hline $\begin{array}{l}\text { 8. Bank decides the sources from where data is to be collected } \\
\text { segregation of collected data }\end{array}$ & 1.000 & .484 \\
\hline 9. The bank decides data collection methods - primary or secondary & 1.000 & .391 \\
\hline $\begin{array}{l}\text { 10. Company takes the responsibilities to process the information and } \\
\text { (n) }\end{array}$ & 1.000 & .562 \\
\hline
\end{tabular}




\begin{tabular}{|l|l|l|}
\hline $\begin{array}{l}\text { 11. Our bank gives training to the job analyst about how to conduct } \\
\text { the process and use the selected methods for collection and recording } \\
\text { job data }\end{array}$ & 1.000 & .583 \\
\hline $\begin{array}{l}\text { 12. Bank prepares job analysis process after a thorough exercise } \\
\text { 13. Company collects job-related data including educational } \\
\text { qualifications of employees, skills and abilities required to perform } \\
\text { the job, working conditions, job activities, reporting hierarchy, } \\
\text { required human traits, job activities, duties and responsible. }\end{array}$ & 1.000 & .543 \\
\hline $\begin{array}{l}\text { 14. Bank is also involved in preparing documents, questionnaires, } \\
\text { interviews and feedback forms to collect data }\end{array}$ & 1.000 & .443 \\
\hline $\begin{array}{l}\text { 15. Proper documentation is done to verify the authenticity of } \\
\text { collected data }\end{array}$ & 1.000 & .556 \\
\hline $\begin{array}{l}\text { 16. Bank reviews the authenticity of the collected data } \\
\text { qualification, experience, personal traits and skills requirement to } \\
\text { perform the job time to time. }\end{array}$ & 1.000 & .527 \\
\hline $\begin{array}{l}\text { 17. My job is described clearly like my roles, activities, duties and } \\
\text { responsibilities of the job }\end{array}$ & 1.000 & .544 \\
\hline $\begin{array}{l}\text { 18. My company verifies job specifications such as, educational } \\
\text { (1) }\end{array}$ & .600 \\
\hline
\end{tabular}

Extraction Method: Principal Component Analysis

Table 5 presents the factors that are related to the evaluation of job analysis process in private commercial banks of Bangladesh. This table shows that (i) data collection process and employee involvement (ii) data authenticity and proper documentation, (iii) training job analyst and developing job analysis method, and (iv) identifying the purpose of job analysis are the important factors concerning the evaluation of job analysis in private commercial banks of Bangladesh. The variance of factor called data collection process and employee involvement is maximum (28.91\%), followed by data authenticity and proper documentation $(8.59 \%)$, training job analyst and developing job analysis method $(7.02 \%)$ and identifying the purpose of job analysis $(6.22 \%)$. The total data set explains 50.74 percent of the total variance which indicates satisfactory results. 
Table 5. Total Variance Explained

\begin{tabular}{|l|l|l|l|}
\hline \multicolumn{3}{|l|}{ Initial Eigenvalues } \\
\hline & Total & $\begin{array}{l}\% \text { of } \\
\text { Variance }\end{array}$ & Cumulative \% \\
\hline $\begin{array}{l}\text { 1. Data Collection Process and Employee } \\
\text { Involvement }\end{array}$ & 5.203 & 28.908 & 28.908 \\
\hline 2. Data Authenticity and Proper Documentation & 1.546 & 8.590 & 37.498 \\
\hline $\begin{array}{l}\text { 3.Training Job Analyst and Developing Job } \\
\text { Analysis Method }\end{array}$ & 1.264 & 7.023 & 44.521 \\
\hline 4. Identifying the Purpose of Job Analysis & 1.119 & 6.218 & 50.740 \\
\hline
\end{tabular}

Extraction Method: Principal Component Analysis

The Rotated Component Matrix (Table 6) shows the four constructs and the factor loadings of each underlying variables of those constructs. The table reveals that the factor loadings of all the variables are very high indicating strong relationship with the constructs.

Table 6. Rotated Component Matrix

\begin{tabular}{|l|l|l|l|l|}
\hline Factors & 1 & 2 & 3 & 4 \\
\hline \multicolumn{2}{|l|}{ Factor 1: Data Collection Process and Employee Involvement } & & & \\
\hline $\begin{array}{l}\text { 2. The bank determines who will conduct job analysis work } \\
\text { 4. Experts don't have any personal likes and dislikes when it } \\
\text { comes to analyze a job }\end{array}$ & .529 & & & \\
\hline $\begin{array}{l}\text { 5. The bank develops a planned approach about how to carry the } \\
\text { whole process in order to investigate a specific job }\end{array}$ & .657 & & & \\
\hline $\begin{array}{l}\text { 6. Company decides the extent of employee involvement in the job } \\
\text { analysis process }\end{array}$ & .638 & & & \\
\hline $\begin{array}{l}\text { 7. My company decides the level of details to be collected and } \\
\text { recorded in the analysis process }\end{array}$ & .644 & & & \\
\hline 8. Bank decides the sources from where data is to be collected & .521 & .367 & & \\
\hline $\begin{array}{l}\text { 9. The bank decides data collection methods - primary or } \\
\text { secondary }\end{array}$ & & & \\
\hline Factor 2: Data Authenticity and Proper Documentation & & & \\
\hline
\end{tabular}




\begin{tabular}{|l|l|l|l|l|}
\hline $\begin{array}{l}\text { 15. Proper documentation is done to verify the authenticity of } \\
\text { collected data }\end{array}$ & .717 & & .698 & \\
\hline 16. Bank reviews the authenticity of the collected data & .687 & & \\
\hline $\begin{array}{l}\text { 17. My job is described clearly like my roles, activities, duties and } \\
\text { responsibilities of the job }\end{array}$ & & .647 & & \\
\hline $\begin{array}{l}\text { 18. My company verifies job specifications such as, educational } \\
\text { qualification, experience, personal traits and skills requirement to } \\
\text { perform the job time to time. }\end{array}$ & & & \\
\hline
\end{tabular}

Factor 3: Training Job Analyst and Developing Job Analysis Method

\begin{tabular}{|c|c|c|}
\hline $\begin{array}{l}\text { 10. Company takes the responsibilities to process the information } \\
\text { and segregation of collected data }\end{array}$ & .617 & \\
\hline $\begin{array}{l}\text { 11. Our bank gives training to the job analyst about how to conduct } \\
\text { the process and use the selected methods for collection and } \\
\text { recording job data }\end{array}$ & .689 & \\
\hline 12. Bank prepares job analysis process after a thorough exercise & 683 & \\
\hline $\begin{array}{l}\text { 13. Company collects job-related data including educational } \\
\text { qualifications of employees, skills and abilities required to perform } \\
\text { the job, working conditions, job activities, reporting hierarchy, } \\
\text { required human traits, job activities, duties and responsibility }\end{array}$ & 635 & \\
\hline $\begin{array}{l}\text { 14. Bank is also involved in preparing documents, questionnaires, } \\
\text { interviews and feedback forms to collect data }\end{array}$ & .494 & \\
\hline \multicolumn{3}{|l|}{ Factor 4: Identifying the Purpose of Job Analysis } \\
\hline 1. My company identifies the purpose of job analysis & & .713 \\
\hline $\begin{array}{l}\text { 3. Expert or HR people determine the way to conduct job analysis } \\
\text { process }\end{array}$ & & .664 \\
\hline
\end{tabular}

\subsection{Results of Confirmatory Factor Analysis}

In the preliminary phases Exploratory Factor Analysis and Test of Reliability of the measurement items are performed where theoretical model is not discovered. Through mathematical explanation Exploratory Factor Analysis does not measure the 


\section{Macrothink}

International Journal of Human Resource Studies

ISSN 2162-3058 2020, Vol. 10, No. 1

unidimensionality of the constructs. (Segars, 1997; O'Leary-Kelly \& Vokurka, 1998; Anderson, 1987; Gerbing \& Anderson, 1988; Koufteros, 1999). Researchers therefore suggest employing the Confirmatory Factor Analysis for a measurement model that evaluates construct unidimensionality. Figure 1 shows the measurement model after Confirmatory

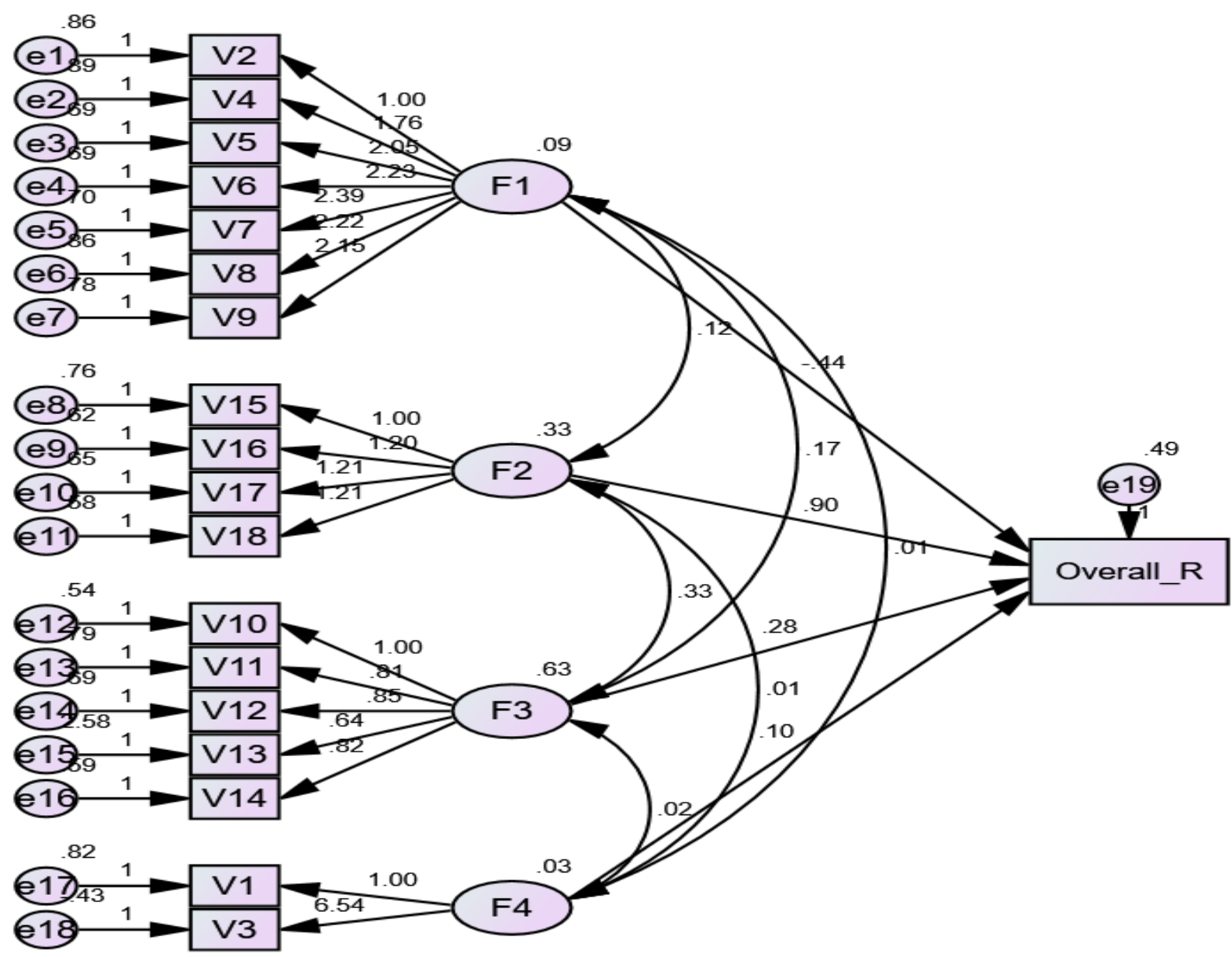

Figure 1. Structural Equation Model

Factor Analysis. (CFA).

Structural Equation Modeling (SEM) has several fitness indices that measure how fit is the model to the data set. Table 7 shows that all the fit indices such as, absolute fit indices, incremental fit indices and parsimonious fit indices confirm the recommended value indicating an excellent fit of the model. 
Table 7. Fit Indices for the Measurement Model

\begin{tabular}{|l|l|l|l|l|}
\hline Name of category & Fit Indices & Meaning & Value & $\begin{array}{l}\text { Recommended } \\
\text { Value }\end{array}$ \\
\hline Absolute Fit & RMSEA & $\begin{array}{l}\text { Root Mean Square of Error } \\
\text { Approximation }\end{array}$ & 0.040 & $>0.08[6]$ \\
\cline { 2 - 5 } & GFI & Goodness of Fit Index & 0.918 & $>0.90[14]$ \\
\hline Incremental Fit & SRMR & $\begin{array}{l}\text { Standardized Root Mean } \\
\text { Square Residual }\end{array}$ & 0.054 & $<0.08[11]$ \\
\cline { 2 - 6 } & TLI & Tucker-Lewis Index & 0.937 & $>0.90[4]$ \\
\hline Parsimonious Fit & $x^{2} /$ df & Relative Chi-Square & 1.351 & $<5.00[17]$ \\
\hline
\end{tabular}

RMSEA (Browne \& Cudeck, 1993); GFI (Jöreskog \& Sörbom, 1984); SRMR (Hair et al., 2016); CFI (Bentler, 1990); TLI (Bentler \& Bonett, 1980); $x^{2} / \mathrm{df}$ (Marsh \& Hocevar, 1985)

\subsection{Results of Multiple Regression Analysis}

Multiple regression analysis was conducted to explore the associative relationships between the dependent variable and the four independent variables. The model summary shows that the coefficient of correlation is 0.575 indicating high correlation among the factors. The adjusted $\mathrm{R}$ square value is 0.319 which indicates that (i) data collection process and employee involvement (ii) data authenticity and proper documentation, (iii) training job analyst and developing job analysis method, and (iv) identifying the purpose of job analysis influence 31.90 percent of the overall job analysis process of the private commercial banks in Bangladesh. (Table 8)

Table 8. Model Summary

\begin{tabular}{|l|l|l|l|l|l|}
\hline Model & $\mathrm{R}$ & R Square & $\begin{array}{l}\text { Adjusted } \\
\text { Square }\end{array}$ & $\begin{array}{l}\text { Std. Error of } \\
\text { the Estimate }\end{array}$ & F Change \\
\hline 1 & $.575^{\mathrm{a}}$ & .331 & .319 & .76624 & 26.965 \\
\hline
\end{tabular}

a. Predictors: (Constant), REGR factor score 4 for analysis 8, REGR factor score 3 for analysis 8 , REGR factor score 2 for analysis 8 , REGR factor score 1 for analysis 8

The Analysis of Variance (ANOVA) shows that all the four factors identified by the factor 
analysis are significantly related to the overall job analysis process in private commercial banks of Bangladesh indicating the acceptance of the model at 1 percent significance level (sig. $\mathrm{F}<0.01$ ). (Table 9).

Table 9. ANOVA

\begin{tabular}{|l|l|l|l|l|l|}
\hline Model & $\begin{array}{l}\text { Sum } \\
\text { Squares }\end{array}$ & of & Mean Square & F & Sig. \\
\hline Regression & 63.326 & 4 & 15.831 & \multirow{2}{*}{26.965} & $.000^{\mathrm{b}}$ \\
\cline { 1 - 5 } Residual & 127.992 & 218 & .587 & & \\
\hline Total & 191.318 & 222 & & & \\
\hline
\end{tabular}

Table 10. Coefficients ${ }^{\mathrm{a}}$

\begin{tabular}{|l|l|l|l|l|l|}
\hline \multirow{2}{*}{ Model } & \multicolumn{2}{|l|}{$\begin{array}{l}\text { Unstandardized } \\
\text { Coefficients }\end{array}$} & $\begin{array}{l}\text { Standardized } \\
\text { Coefficients }\end{array}$ & & \\
\cline { 2 - 6 } & B & Std. Error & Beta & t Sig. \\
\hline Constant) & 3.803 & .051 & & 74.110 & .000 \\
\hline $\begin{array}{l}\text { 1.Data Collection Process and Employee } \\
\text { Involvement Authenticity and Proper }\end{array}$ & .412 & .051 & .444 & 3.517 & .001 \\
\hline $\begin{array}{l}\text { 2.Data } \\
\text { Documentation }\end{array}$ & .051 & .195 & 8.013 & .000 \\
\hline $\begin{array}{l}\text { 3.Training Job Analyst and Developing Job } \\
\text { Analysis Method }\end{array}$ & .284 & .051 & .306 & 5.519 & .000 \\
\hline 4.Identifying the Purpose of Job Analysis & .046 & .051 & .050 & .900 & .369 \\
\hline
\end{tabular}

a. Dependent Variable: 19. Considering all the factors mentioned above, I think our bank seriously analyze each job of the bank

The Multiple Regression shows that factors such as data collection process and employee involvement $(\beta 1=0.195$; t-statistic $=3.517 ; \mathrm{p}<0.05)$, Data Authenticity and Proper Documentation $(\beta 2=0.444$; t-statistic $=8.013 ; \mathrm{p}<0.05)$ and Training Job Analyst and Developing Job Analysis Method $(\beta 3=0.306 ; \mathrm{t}$-statistic $=5.519 ; \mathrm{p}<0.05)$ are significantly related to the overall job analysis process of the private commercial banks in Bangladesh at 5 
percent significance level, thus supporting $\mathrm{H} 1, \mathrm{H} 2$ and $\mathrm{H} 3$. On the other hand, Identifying the purpose of job analysis factor $(\beta 2=0.050$; t-statistic $=0.900 ; \mathrm{p}>0.05)$ is not significantly related to the overall job analysis process of the private commercial banks in Bangladesh, thus not supporting hypothesis H4. (Table 10).

\subsection{Discussion of Results}

\subsubsection{Data Collection Process and Employee Involvement}

The commercial banks need to identify the sources of data which includes job analyst, employee, supervisor and determine the method of data collection. The bank develops a planned approach about how to carry the whole process in order to investigate a specific job. It decides the level of details to be collected and the extent of employee involvement in the job analysis process.

\subsubsection{Data Authenticity and Proper Documentation}

The commercial banks of Bangladesh verify job specifications such as, educational qualification, experience, personal traits and skills requirement to perform the job time to time. Proper documentation is done to verify the authenticity of collected data. After that bank reviews the authenticity of the collected employee data.

\subsubsection{Training Job Analyst and Developing Job Analysis Method}

Bangladeshi Banks prepare job analysis process after a thorough exercise. The collects job-related data including educational qualifications of employees, skills and abilities required to perform the job, working conditions, job activities, reporting hierarchy, required human traits, job activities, duties and responsibility. Bank is also involved in preparing documents, questionnaires, interviews and feedback forms for data collection. It takes the responsibilities to process the information and segregation of collected data. The commercial banks provide training to the job analysts about how to conduct the process and use the selected methods for collection and recording job data.

\section{Conclusions and Recommendations}

This study was designed to evaluate the job analysis process of private commercial banks in Bangladesh. The findings revealed that all the variables concerning job analysis process of private commercial banks have high level of communalities. The KMO and Bartlett's test suggested that factor analysis was suitable for this research. The Exploratory Factory Analysis (EFA) shows that four factors such as, (i) data collection process and employee involvement (ii) data authenticity and proper documentation, (iii) training job analyst and developing job analysis method, and (iv) identifying the purpose of job analysis are related to the overall job analysis process of the banks. These factors explain 50.74 percent of the total variance of job analysis process of private commercial banks. The Confirmatory Factor Analysis (CFA) reveals that the fit indices of the model are well above the recommended values indicating an excellent fit of the model to the data set. Multiple regression analysis shows that among the four factors data collection process and employee involvement, data authenticity and proper documentation, and training job analyst and developing job analysis 
method are significantly related to the overall job analysis process. This study therefore, recommends that human resource managers of the banks should focus more on developing effective job analysis method, data collection process, maintain data authenticity and training the job analysts for getting maximum benefit from job analysis. One of the limitations of this research is that the study surveyed employees from only 12 banks situated in Dhaka city. However, a wider geographic sampling including other big cities of Bangladesh would reflect the national profile better. Hence, there is a good scope to conduct further research by taking more sample into account to get more precise results.

\section{References}

Ash, R. A. (1988). Job analysis in the world of work. The job analysis handbook for business, industry, and government, 1, 3-13.

Ash, R. A., \& Levine, E. L. (1980). A framework for evaluating job analysis-methods. Personnel, 57(6), 53-59.

Bentler, P. M. (1990). Comparative fit indexes in structural models. Psychological bulletin, 107(2), 238. https://doi.org/10.1037/0033-2909.107.2.238

Bentler, P. M., \& Bonett, D. G. (1980). Significance tests and goodness of fit in the analysis of covariance $\quad$ structures. Psychological bulletin, 88(3), 588. https://doi.org/10.1037/0033-2909.88.3.588

Brannick, M. T., Levine, E. L., \& Morgeson, F. P. (2007). Job and work analysis: Methods, research, and applications for human resource management (2nd ed.). Thousand Oaks, CA, US: Sage Publications, Inc. https://doi.org/10.4135/9781483329505

Browne, M. W., \& Cudeck, R. (1993). Alternative ways of assessing model fit. Sage focus editions, 154, 136-136.

Byars, L. L., \& Rue, L. W. (2006). Human Resource Management (8 Ed.). New York: The McGraw-Hill.

Dabholkar, P. A., Thorpe, D. I., \& Rentz, J. O. (1996). A measure of service quality for retail stores: scale development and validation. Journal of the Academy of marketing Science, 24(1), 3. https://doi.org/10.1007/BF02893933

Drucker, P. F. (2002). They're not employees, they're people. Harvard Business Review, 80(2), 70-7.

Gerbing, D. W., \& Anderson, J. C. (1988). An updated paradigm for scale development incorporating unidimensionality and its assessment. Journal of marketing research, 25(2), 186-192. https://doi.org/10.1177/002224378802500207

Hair Jr, J. F., Hult, G. T. M., Ringle, C., \& Sarstedt, M. (2016). A primer on partial least squares structural equation modeling (PLS-SEM). Sage publications. https://doi.org/10.15358/9783800653614

Hair, J. F., Anderson, R. E., Tatham, R. L., \& Black, W. C. (1998). Multivariate data analysis. Upper Saddle River. 
Holst, E., \& Pancoast, E. (1921) Scientific Method in Job Analysis. Journal of Political Economy, 29(6), 508-516. https://doi.org/10.1086/253367

Jöreskog, K. G., \& Sörbom, D. (1984). LISREL-VI user's guide 3rd edn. IN: Scientific Software, Mooresville.

Koufteros, X. A. (1999). Testing a model of pull production: a paradigm for manufacturing research using structural equation modeling. Journal of operations Management, 17(4), 467-488. https://doi.org/10.1016/S0272-6963(99)00002-9

Luthans, F. (2002). Organizational Behavior, 9th edition, New York: McGraw-Hill.

Marsh, H. W., \& Hocevar, D. (1985). Application of confirmatory factor analysis to the study of self-concept: First-and higher order factor models and their invariance across groups. Psychological bulletin, 97(3), 562. https://doi.org/10.1037/0033-2909.97.3.562

McCormick, E. J., DeNisi, A. S., \& Shaw, J. B. (1979). Use of the position analysis questionnaire for establishing the job component validity of tests. Journal of Applied Psychology, 64(1), 51. https://doi.org/10.1037/0021-9010.64.1.51

Nunnally, J. U. M. (1994). C., BERSTEIN, Ira H. Psycometric theory. New York: McGraw Hill.

O'Leary-Kelly, S. W., \& Vokurka, J. R. (1998). The empirical assessment of construct validity. Journal of operations management, 16(4), 387-405. https://doi.org/10.1016/S0272-6963(98)00020-5

Pearn, M. A., \& Kandola, R. S. (1993). Job analysis: a manager's guide. Institute of Personnel Management.

Pinnington, A., \& Edwards, T. (2000). Introduction to human resource management. OUP Catalogue.

Practical and Professional Management Signatures (PPMS) (2018). Human Resources Management. (Lecture manual). Practical and Professional Management Signatures

Prien, E. P. (1977). The Function of Job Analysis in Content Validation 1. Personnel Psychology, 30(2), 167-174. https://doi.org/10.1111/j.1744-6570.1977.tb02086.x

Prien, E. P., Goodstein, L. D., Goodstein, J., \& Gamble Jr, L. G. (2009). A practical guide to job analysis. John Wiley \& Sons.

Rehman, M. S. (2009). Impact of job analysis on job performance: A study of public sector organizations of Pakistan (Doctoral dissertation, NATIONAL UNIVERSITY OF MODERN LANGUAGES ISLAMABAD).

Segars, A. H. (1997). Assessing the unidimensionality of measurement: A paradigm and illustration within the context of information systems research. Omega, 25(1), 107-121. https://doi.org/10.1016/S0305-0483(96)00051-5

Singh, P. (2008). Job analysis for a changing workplace. Human Resource Management Review, 18(2), 87-99. https://doi.org/10.1016/j.hrmr.2008.03.004 


\section{Macrothink}

International Journal of Human Resource Studies

ISSN 2162-3058 2020, Vol. 10, No. 1

Suthar, B. K., Chakravarthi, T. L., \& Pradhan, S. (2014). Impacts of Job Analysis on Organizational Performance: An Inquiry on Indian Public Sector Enterprises. Procedia Economics and Finance, 11, 166-181. https://doi.org/10.1016/S2212-5671(14)00186-5

\section{Copyright Disclaimer}

Copyright for this article is retained by the author(s), with first publication rights granted to the journal.

This is an open-access article distributed under the terms and conditions of the Creative Commons Attribution license (http://creativecommons.org/licenses/by/4.0/). 